\title{
PENGEMBANGAN INSTRUMEN PEMAHAMAN KONSEP BERBASIS KOMPUTER PADA PEMBELAJARAN KIMIA
}

\section{COMPUTER BASED CONCEPT UNDERSTANDING INSTRUMENS IN CHEMICAL LEARNING}

\author{
Muhammad Shohibul Ihsan $^{1 *}$, Saprizal Hadisaputra ${ }^{2}$, Agus Ramdani $^{3}$, Agil Al Idrus ${ }^{3}$ \\ ${ }^{1}$ Program Studi Biologi FMIPA Universitas Nahdlatul Wathan Mataram, Indonesia \\ ${ }^{2}$ Program Studi Pendidikan Kimia, Fakultas Keguruan dan Ilmu Pendidikan, Universitas Mataram \\ ${ }^{3}$ Program Studi Pendidikan Biologi, Fakultas Keguruan dan Ilmu Pendidikan, Universitas Mataram \\ *Email: ihsan@unwmataram.ac.id
}

Diterima: 22 Januari 2020. Disetujui: 02 Februari 2020. Dipublikasikan: 21 April 2020

\begin{abstract}
Abstrak: Penelitian ini bertujuan untuk menghasilkan instrumen pemahaman konsep berbasis komputer yang valid sebagai alat ukur pemahaman konsep peserta didik pada mata pelajaran kimia dengan materi pokok struktur atom. Penelitian ini termasuk dalam penelitian dan pengembangan (Research and Development) mengacu pada model pengembangan ADDIE meliputi tahap Analysis, Design, Development, Implementation, Evaluation. Pengujian instrumen dalam pembelajaran dilakukan pada peserta didik kelas X MIA MA Nahdlatul Wathan Mataram, NTB. Desain uji coba penelitian ini menggunakan One Group Pretest-Posttest Design. Hasil penelitian menunjukkan bahwa persentase rata-rata nilai kelayakan instrumen dari ketiga validator sebesar $86.3 \%$ dengan kriteria sangal layak. Penggunan instrumen pemahaman konsep berbasis komputer pada uji coba terbatas mendapatkan nilai ratarata dari guru dan peserta didik sebesar $80.4 \%$ dengan kriteria sangat praktis. Hasil ini menunjukkan bahwa media instrumen pemahaman konsep berbasis komputer yang dikembangkan memiliki kriteria valid dan praktis untuk meningkatkan pemahaman konsep peserta didik.
\end{abstract}

Kata Kunci : Instrumen, Pemahaman Konsep, Komputer, Pembelajaran Kimia

Abstract: This study aims to create a valid computer-based concept understanding instrumen as a measurement tool for students' understanding of chemistry subjects with basic ingredients of atomic structure. Research, including research and development (Research and Development) discusses the ADDIE development model, including Analysis, Design, Development, Implementation, Evaluation. Testing instrumens in learning is carried out on class X MIA MA Nahdlatul Wathan Mataram, NTB. Design research trials using One Group Pretest-Posttest Design. The results showed that the average value of the instrumen worthiness of the three validators was $82.2 \%$ with very reasonable criteria. The use of computer-based concept understanding instrumens in limited trials gained an average score of $80.5 \%$ from teachers and students with very practical criteria. The results of this study prove that the media developed have valid and practical concepts to increase students' understanding.

Keywords: Instrumens, Concept Understanding, Computers, Chemical Learning

\section{PENDAHULUAN}

Era revolusi industri 4.0 merupakan era dimana kehidupan sumber daya manusia berorientasi pada penggunaan teknologi, tiadak terlepas dalam dunia pendidikan. [1] Era ini sebagai tantangan bagi dunia pendidikan seperti perubahan cara belajar peserta didik yang lebih memanfaatkan penggunaan teknologi sebagai sumber belajar dan media pembelajaran, sehingga peran pendidik untuk meningkatkan kualitas pembelajaran dalam menghadapi era ini sangat dibutuhkan dalam menyampaikan materi pembelajaran khususnya materi kimia Pembelajaran kimia kepada peserta didik [2].

Perkembangan teknologi dalam dunia pendidikan menuntut guru lebih berperan aktif dalam proses pembelajaran. Untuk mempermudah guru menyampaikan materi pembelajaran khususnya dalam pembelajaran kimia, diperlukan langkah nyata agar peserta didik mudah menerima materi yang disampaikan. Dalam mewujudkan hal tersebut beberapa langkah perlu dilakukan, misalnya mendesain materi ajar dan tes dalam bentuk teknologi seperti multimedia [3].

Kajian pembelajaran ilmu kimia menuntut peserta didik mampu memahami konsep-konsep yang mikroskopis dan abstrak, namun materi kimia kerap kali dirasakan sulit oleh peserta didik sehingga semangat belajarnya menurun [4]. Banyak peserta didik di sekolah menengah memiliki banyak kesulitan dalam memahami pembelajran kimia [5]. Banyak peserta didik pada kenyataannya, hanya menghafal konsep-konsep kimia tanpa benar-benar belajar [6]. 
Kondisi kesulitan yang dialami peserta didik terhadap pelajaran kimia tentunya berujung pada ketercapaian hasil pembelajaran yaitu ketidakmampuan peserta didik untuk memahami dan menggunakan konsep kimia pada berbagai situasi [7].

Pemahaman konsep merupakan salah satu pengetahuan awal yang harus dimiliki oleh peserta didik karena pemahaman konsep merupakan dasar dalam merumuskan prinsip-prinsip. Pemahaman konsep mengacu pada kemampuan peserta didik untuk memahami makna secara ilmiah, baik teori maupun aplikasi kehidupan sehari-hari. Peserta didik yang memahami konsep akan dapat menyelesaikan masalah yang disajikan ke dalam berbagai bentuk penyelesaian [8]. Pemahaman konsep kimia diperoleh dari pemahaman teoritis dan empiris melalui kegiatan eksperimen, sehingga peserta didik dapat merekam dan mentransfer beberapa informasi untuk digunakan dalam masalah memecahkan, menganalisis, dan mengaplikasikan dalam kehidupan sehari-hari [9].

Hasil observasi yang dilakukan pada proses pembelajaran di kelas menunjukkan, peserta didik hanya memperoleh informasi dari pendidik tanpa mengolah informasi tersebut lebih lanjut dan tidak mengaitkan materi dengan kehidupan sehari-hari, serta pendidik jarang menggunakan media sebagai sumber belajar.

Pembelajaran dengan menggunakan multimedia interaktif memungkinkan peserta didik untuk fokus pada konten, multimedia interaktif memuat unsurunsur media secara lengkap yang meliputi audio animasi, video, teks, dan grafis yang memungkinkan pengguna untuk berinteraksi secara interaktif melalui fitur-fitur yang tersedia [10].

Proses-proses kognitif dalam aspek memahami meliputi menafsirkan, mencontohkan, mengklasifikasikan, merangkum, menarik inferensi, membandingkan dan menjelaskan [11].

Mendesain media yang praktis dan efektif harus melalui proses validasi. Sebelum digunakan untuk uji pemakaian produk, maka perlu dilakukan uji validitas media pembelajaran. Validasi media pembelajaran dimaksudkan untuk memastikan bahwa media pembelajaran yang telah dibuat layak digunakan dan dapat mengukur apa yang hendak diukur. Validitas menunjukan derajat ketepatan antara data yang sesungguhnya terjadi pada objek dengan data yang dikumpulkan oleh peneliti [12]

Berdasarkan uraian diatas, maka penelitan ini bertujuan untuk menghasilkan suatu produk berupa instrumen pemahaman konsep berbasis komputer dalam pembelajaran kimia yang yang layak, efektif dan praktis.

\section{METODE PENELITIAN}

Penelitian ini termasuk dalam penelitian pengembangan (Research and Development) yang merupakan metode penelitian yang digunakan untuk menghasilkan produk tertentu (kreasi), dan menguji keefektifan produk tersebut [13].

Produk pengembangan yang dimaksud berupa instrumen pemahaman konsep berbasis komputer yang di rancang dengan tujuan sebagai alat ukur pemahaman konsep peserta didik. Model pengembangan dalam penelitian ini mengacu pada model pengembangan ADDIE, yang dikembangkan oleh [14] meliputi 5 tahap yaitu Analysis, Design, Development, Implementation dan Evaluation. Tatapi pada penelitan ini terbatas samapai pada tahap pengembangan.

Produk hasil pengembangan divalidasi oleh tim ahli. Data validasi dari ahli dianalisis secara kualitatif sebagai masukan untuk memperbaiki produk yang dikembangkan [15]. Data angket mengenai tanggapan ahli terkait kelayakan produk pengembangan dianalisis dengan cara mentranspormasi skor rata-rata dari keseluruhan aspek yang diamati kedalam kalimat yang bersifat kualitatif dengan kriteria seperti pada Tabel 1.

Tabel 1. Kriteria kelayakan e-learning

\begin{tabular}{cc}
\hline $\begin{array}{c}\text { Persentase Hasil } \\
\text { Penilaian (\%) }\end{array}$ & Tingkat Kelayakan \\
\hline $80-100$ & Sangat layak \\
$66-79$ & Layak \\
$56-65$ & Cukup layak \\
$40-55$ & Kurang layak \\
$30-39$ & Tidak Layak \\
\hline
\end{tabular}

\section{HASIL DAN PEMBAHASAN \\ Hasil Tahap Analisis}

Tahap analisis adalah tahap awal dalam mengembangkan instrumen pemahaman konsep berbasis komputer. Pada tahap ini dilakukan analisis masalah dan kebutuhan peserta didik.

Analisis maslah dilakukan untuk menentukan masalah dasar dalam pengembangan instrumen pemahaman konsep berbasis komputer. Pada langkah ini, peneliti mengamati permasalahan-permasalahan yang muncul dalam tes/ujian pada mata pelajaran Kimia kelas X MIA. Analisis kebutuhan peserta didik yaitu peserta didik membutuhkan inovasiinovasi baru dalam tes akhir pembelajaran kimia yang mampu diakses secara online, dan instrumen yang bisa menjelaskan konten soal materi mikroskopis, inovasi ini sebagai tawaran peneliti yaitu dengan mengembangkan instrumen pemahaman konsep berbasis komputer yang interaktif dengan dukungan gambar, animasi dan video pembelajaran. 


\section{Hasil Tahap Perencanaan}

Tahap perencanaan dimulai dari proses sistematik dengan menyusun flowchart dan storyboard sebagai dasar dan gambaran bentuk, tampilan dalam mengembangkan instrumen pemahaman konsep berbasis komputer. Instrumen pemahaman konsep yang dikembangkan dalam bentuk instrumen pilihan ganda yang terdiri dari 5 (lima) opsi jawaban.

\section{Hasil Tahap Pengembangan}

Tahap ini merupakan tahapan pembuatan instrumen pemahaman konsep berbasis komputer. Instrumen pemahman konsep yang dikembangkan dalam penelitian ini ada 6 (enam) dari 7 (tujuh) indikator pemahaman konsep yaitu menjelaskan, membandingkan, menafsirkan, mencontohkan, mengklasifikasikan dan menyimpulkan.

Instrumen pemahaman konsep berbasis komputer yang dikembangkan memuat halaman depan, dengan konten nama peserta didik, sebaran kelas, waktu pengerjaan soal, serta sebaran soal interaktif yang mendukung untuk dapat menjelaskan soal-soal yang mikroskopis dan abstrak dengan dukungan gambar, animasi dan video materi pada soal.

\section{Hasil Validasi}

Validasi produk hasil pengembangan berupa instrumen pemahaman konsep berbasis komputer dilakukan oleh tiga orang ahli yang berkompoten dalam bidangnya. Hasil validasi ahli yang diperoleh dicantumkan pada Tabel 2.

Tabel 2. Hasil validasi produk hasil pengembangan

\begin{tabular}{ccc}
\hline Validator & Instrumen (\%) & Kriteria \\
\hline I & 80 & Sangat layak \\
II & 81 & Sangat layak \\
III & 68 & Layak \\
Rata-rata & 76.3 & Layak \\
\hline
\end{tabular}

Berdasarkan tabel 2 menunjukkan bahwa presentase rata-rata hasil validasi/kelayakan instrumen pemahaman konsep sebesar $76.3 \%$ dengan kriteria layak, sehingga instrumen pemhaman konsep berbasis komputer dapat diimplementasikan dalam pembelajaran.

\section{Hasil Uji Coba Terbatas}

Uji coba terbatas dilakukan bertujuan mengetahui kepraktisan dan keterbacaan [16] produk hasil pengembangan. Uji ini dilakukan oleh guru dan peserta didik disebabkan karena keduanya merupakan pengguna dari instrumen yang dikembangkan. Hasi uji kepraktisan instrumen pemahaman konsep berbasis komputer terhadap guru dan peserta didik dicantuman pada Tabel 4 .

Tabel 3. Hasil respon guru dan peserta didik

\begin{tabular}{ccc}
\hline Responden & Rata-rata (\%) & Kriteria \\
\hline Guru & 82 & Sangat praktis \\
Peserta Didik & 79 & Sangat praktis \\
Rata-rata & 80.5 & Sangat Praktis \\
\hline
\end{tabular}

Berdasarkan tabel 3 menunjukkan bahwa presentase rata-rata hasil uji coba instrumen pemahaman konsep berbasis komputer sebesar $80.5 \%$ dengan kriteria sangat praktis, sehingga instrumen pemhaman konsep berbasis komputer dapat diimplementasikan dalam pembelajaran dengan skala lebih luas.

Hasil uji kepraktisan instrumen pemahaman konsep berbasis komputer memiliki efek yang sangat signifikan dalam penggunaanya dan hasilnya oleh peserta didik. Kemampuan pemahaman konsep peserta didik sebelum diterapkan (pretest) instrumen pemahaman konsep berbasis komputer dengan setelah diterapkannya (posttest) instrumen pemahaman konsep berbasis komputer memiliki kemampuan menyelesaiakan soal pemahaman konsep yang lebih baik dari sebelum di terapkannnya. Hal ini sejalan dengan penelitian [17] media e-learning dinyatakan layak sebagai media pembelajaran. Burrows [18] menjelaskan bahwa asfek interaktif yang termuat dalam isi soal dapat memperbaiki pemahaman konsep peserta didik

\section{KESIMPULAN}

Instrumen pemahaman konsep berbasis komputer dapat digunakan sebagai alat untuk mengukur pemahaman konsep peserta didik, terutama dalam mata pelajaran kimia materi struktur atom. nstrumen pemahaman konsep berbasis komputer memfasilitasi dan memaksimalkan kemampuan peserta didik dalam menjawab soal kimia secara interaktif.

\section{DAFTAR PUSTAKA}

[1] Ihsan, M. S., Ramdani, A., \& Hadisaputra, S. (2019). Pengembangan E-Learning Pada Pembelajaran Kimia Untuk Meningkatkan Kemampuan Berpikir Kritis Peserta Didik. Jurnal Pijar Mipa, 14(2), 84-87

[2] Utami, G. R., Firman, H., \& Nahadi, N. (2019, February). Development of computer based two-tier multiple choice diagnostic test to identify misconceptions on chemical bonding. In Journal of Physics: Conference Series (Vol. 1157, No. 4, p. 042033). IOP Publishing.

[3] Yustiqvar, M., Gunawan, G., \& Hadisaputra, S. (2019, December). Green Chemistry Based Interactive Multimedia on Acid-Base Concept. In Journal of Physics: Conference Series (Vol. 1364, No. 1, p. 012006). IOP Publishing.

[4] Yustiqvar, M., Hadisaputra, S., \& Gunawan, G. (2019). Analisis Penguasaan Konsep Siswa yang Belajar Kimia Menggunakan Multimedia Interaktif Berbasis Green Chemistry. Jurnal Pijar Mipa, 14(3), 135-140.

[5] Iftitahurrahimah, I., Andayani, Y., \& Al Idrus, S. W. (2020). Pengaruh Model Problem Based Learning (PBL) Terhadap Kemampuan Komunikasi Siswa Materi Pokok Larutan Elektrolit Dan Non-Elektrolit. Jurnal Pijar Mipa, 15(1), 7-12. 
[6] Pebriana, L., Sukib, S., \& Junaidi, E. (2018). Pengaruh Model Pembelajaran Berbasis Masalah dengan Tipe Group Investigation (Gi) Terhadap Hasil Belajar Kimia Siswa. Chemistry Education Practice, 1(1), 6-12.

[7] Rain, L. Z., Purwoko, A. A., \& Hakim, A. (2019). Pengaruh Model Pembelajaran Kooperatif Tipe Rotating Trio Exchange Dengan Pendekatan Brain-Compatible Learning Terhadap Hasil Belajar Kimia Pada Siswa Kelas X Di SMA Negeri 1 Lingsar Tahun Ajaran 2013/2014. Jurnal Ilmiah Pendidikan Indonesia, 1(1), 15-25.

[8] Wicaksono, I., \& Wasis, M. (2017). The effectiveness of virtual science teaching model (VS-TM) to Improve Student's Scientific Creativity and Concept Mastery on Senior High School Physics Subject. Journal of Baltic Science Education, 16(4), 549.

[9] Zulkarnain, Z., Andayani, Y., \& Hadisaputra, S. (2019). Peningkatan Keterampilan Berpikir Kritis Peserta Didik Pada Pembelajaran Kimia Menggunakan Model Pembelajaran Preparing Dong Concluding. Jurnal Pijar Mipa, 14(2), 96-100.

[10] Yulianci, S., Gunawan, G., \& Doyan, A. (2017). Model Inkuiri Terbimbing Berbantuan Multimedia Interaktif Untuk Meningkatkan Penguasaan Konsep Fisika Peserta Didik. Jurnal Pendidikan Fisika dan Teknologi, 3(2), 146-154.

[11] Anderson, L. W., \& Krathwohl, D. R. (2001). A revision of Bloom's taxonomy of educational objectives. A Taxonomy for Learning, Teaching and Assessing. Longman, New York.

[12] Sugiyono. 2018. Metode Penelitian Kuantitatif, Kualitatif $R \& D$. Bandung: Penerbit Alfabeta

[13] Sugiyono. 2017. Metode Penelitian \& Pengembangan. Bandung: Penerbit Alfabeta

[14] Muruganantham, G. (2015). Developing of Econtent package by using ADDIE model. International Journal of Applied Research, 1(3), 52-54.

[15] Ernawati, I., dan Sukardiyono, T. 2017. Uji Kelayakan Media Pembelajaran Interaktif Pada Mata Pelajaran Adiminstrasi Server. Universitas Negeri Yogyakarta. Jurnal Elinvo (Electronics, Informatics, and Vocational Education), Volume 2, Nomor 2

[16] Nisyah, M., Gunawan., Harjono., A \& Kusdiastuti., M. 2019. Perangkat Pembelajaran Model Inkuiri Dipadu Advance Organizer Untuk Meningkatkan Penguasaan Konsep Dan Kemampuan Pemecahan Masalah Fisika Siswa. Jurnal Pijar MIPA, 14(2):1-6
[17] Hikmah, N., Saridewi, N., \& Agung, S. (2017). Penerapan laboratorium virtual untuk meningkatkan pemahaman konsep siswa. EduChemia (Jurnal Kimia dan Pendidikan), 2(2), 186-195.

[18] Burrows, N. L., \& Mooring, S. R. (2015). Using concept mapping to uncover students' knowledge structures of chemical bonding concepts. Chemistry Education Research and Practice, 16(1), 53-66. 